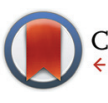

CrossMark \& click for updates

Cite this: Dalton Trans., 2014, 43 13704

Received 6th June 2014,

Accepted 24th July 2014

DOI: $10.1039 / c 4 d t 01681$ e

www.rsc.org/dalton

\title{
Synthesis and structural investigation of $\mathrm{R}_{\mathbf{2}} \mathrm{Si}$ ( $\mathrm{R}=\mathrm{Me}, \mathrm{Ph})$ bridged di-N-heterocyclic carbenes $\uparrow$
}

\author{
Rajendra S. Ghadwal,* Sven O. Reichmann, Elena Carl and Regine Herbst-Irmer
}

Functionalization of the $\mathrm{C} 4$ carbon of an imidazol-derived $\mathrm{N}$-heterocyclic carbene (NHC) may allow finetuning of the electronic and steric properties of the $\mathrm{C} 2$ carbene center. A facile route to silyl-functionalized di-N-heterocyclic carbenes (Di-NHCs) is described. Treatment of the polymeric lithiated NHC, $\left\{\mathrm{Li}\left(\operatorname{IPr}^{\mathrm{H}}\right)\right\}_{n}(\mathbf{1})\left(\mathrm{Li}\left(\operatorname{IPr}^{\mathrm{H}}\right)=\left\{\left(\mathrm{N}-2,6-i \operatorname{Pr}_{2} \mathrm{C}_{6} \mathrm{H}_{3}\right)_{2} \mathrm{CHCLi}\right\} \mathrm{C}:\right)$ with a dichlorosilane affords monomeric silyl-functionalized Di-NHCs, $\mathrm{R}_{2} \mathrm{Si}\left(\mathrm{IPr}^{\mathrm{H}}\right)_{2}(\mathrm{R}=\mathrm{Ph}, 2 ; \mathrm{Me}, 3)$. Interestingly, silyl-functionalized mono-NHC, $\mathrm{Ph}_{2}(\mathrm{Cl}) \mathrm{Si}$ $\left(\operatorname{Pr}^{\mathrm{H}}\right)(4)$ with a pendant chloro-substituent can also be exclusively isolated maintaining the reactants 1 and $\mathrm{Ph}_{2} \mathrm{SiCl}_{2}$ ratio. NHCs 2 and 4 readily form copper complexes, $\mathrm{Ph}_{2} \mathrm{Si}\left\{\left(\mathrm{IPr}^{\mathrm{H}}\right) \mathrm{CuCl}\right\}_{2}(\mathbf{5})$ and $\mathrm{Ph}_{2}(\mathrm{Cl}) \mathrm{Si}$ $\left\{\left(\mathrm{Pr}^{\mathrm{H}}\right) \mathrm{CuCl}\right\}$ (6), on reaction with $\mathrm{CuCl}$. Straightforward conversion of an NHC to a Di-NHC (2 or 3) via C4 functionalization is reported for the first time. Molecular structures of 2, 4, 5 and $\mathbf{6}$ have been established by single crystal $\mathrm{X}$-ray diffraction studies.

\section{Introduction}

N-heterocyclic carbenes (NHCs), which were originally considered as simple phosphine mimics, have established exceptional applications beyond ligands in organometallic and transition metal catalysis. ${ }^{1-5}$ The utility of NHCs has expanded from the stabilization of elusive compounds with a low-valent main group element ${ }^{3}$ or complexes with a metal in the highoxidation state $^{2}$ to the pharmaceuticals ${ }^{4}$ and materials science. ${ }^{5}$ The success of NHCs as ligands in catalysis is largely attributed to their strong $\sigma$-donor properties and relatively high covalent contribution to the metal- $\mathrm{C}_{(\text {carbene) }}$ bond. ${ }^{6}$ A very small modification in the structure may have a significant impact on the properties of an NHC and hence derived metal complexes as well as related species. ${ }^{7}$ A unique structural feature allows fine-tuning of NHCs in more ways, therefore a variety of NHCs with variable structural and electronic properties has been prepared. ${ }^{8}$ Interesting poly-NHCs featuring two or more carbene functionalities have been reported; however, a majority of them is linked via the nitrogen atom of the imidazol ring. ${ }^{9-14}$ In addition to their applications as ligands in catalysis, ${ }^{9}$ such poly-NHCs have shown their poten-

Institut für Anorganische Chemie, Georg-August-Universität Göttingen,

Tammannstrasse 4, 37077 Göttingen, Germany.

E-mail: rghadwal@uni-goettingen.de

$\dagger$ Electronic supplementary information (ESI) available: NMR spectra of 2-6 and X-ray crystallographic information on 2, 4, 5 and 6 are provided. CCDC 982101 (2), 982103 (4), 982104 (5) and 982102 (6). For ESI and crystallographic data in CIF or other electronic format see DOI: 10.1039/c4dt01681e tial as building-blocks to design a new class of structurally dynamic materials. ${ }^{14}$

Among available methods of fine-tuning, functionalization of NHCs impacts the properties as well as allows access to a new class of NHCs. ${ }^{15-22}$ The prospect of direct access to functionalized NHCs from an NHC, with p-block moieties in particular, is enormous as it enables the synthesis of new ligands. Functionalization of an imidazol-2-ylidene with a phosphaalkene was first observed by Gates et al. to yield a 4-phosphinosubstituted NHC (Scheme 1, I) ${ }^{16}$ Bertrand et al. developed a method for the preparation of 4-substituted imidazol-2ylidenes (Scheme 1, II) by deprotonation of a C2-substituted imidazolium salt. ${ }^{17}$ Formation of II presumably occurs via 1,3 rearrangement of an imidazol-4-ylidene (mesoionic carbene) intermediate. Nevertheless, stable metal-free imidazol-4ylidenes have also been reported by the same group. ${ }^{23}$ Functionalization of an NHC has also been achieved with a silylene ( $\mathrm{IPr}) \mathrm{SiCl}_{2}$, when treated with adamantyl azide (Scheme 1, III). ${ }^{18}$ Robinson et al. revealed a facile route to a lithiated NHC, $\mathrm{Li}\left(\operatorname{IPr}^{\mathrm{H}}\right)(\mathbf{1})\left(\mathrm{Li}\left(\operatorname{IPr}^{\mathrm{H}}\right)=\left\{\left(\mathrm{N}-2,6-i \mathrm{Pr}_{2} \mathrm{C}_{6} \mathrm{H}_{3}\right)_{2} \mathrm{CHCLi}\right\} \mathrm{C}:\right),{ }^{19}$ which has
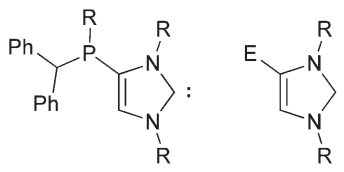

$$
\left(\mathrm{R}=2,4,6-\mathrm{Me}_{3} \mathrm{C}_{6} \mathrm{H}_{2}\right)
$$

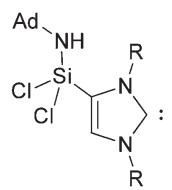
$\stackrel{\text { III }}{(\text { Ad }=\text { adamantyl })}$

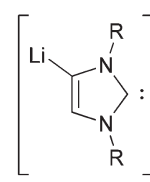

(1)
$\left(\mathrm{R}=2,6-i \mathrm{Pr}_{2} \mathrm{C}_{6} \mathrm{H}_{3}\right)$

$\left.\mathrm{Me}_{3} \mathrm{Si}, \mathrm{Ph}_{2} \mathrm{P}\right)$
$\mathrm{B}$

Scheme 1 C4 functionalized mono-NHCs. 


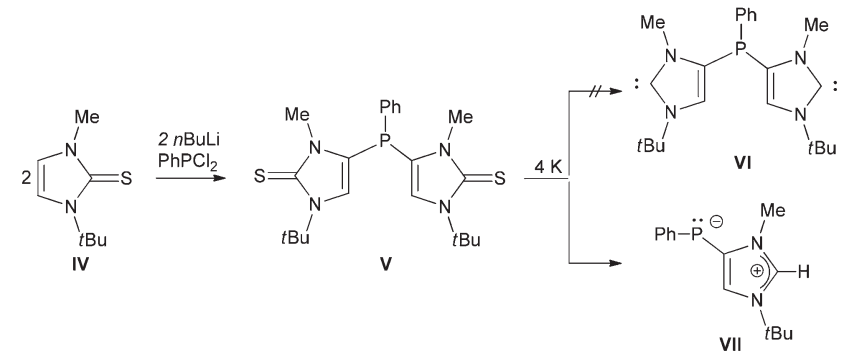

Scheme 2 Reaction of di-thione (V) with potassium metal.

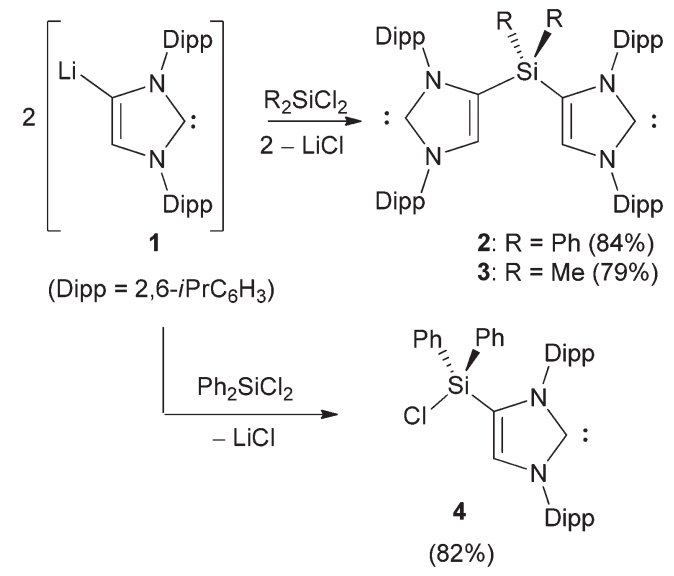

Scheme 3 Reaction synthesis of NHDCs 2 and 3 and mono-NHC 4.

facilitated the access to new molecular scaffolds with interesting properties and applications. ${ }^{20}$

Treatment of an NHC-precursor, 1-methyl-3-tert-butyl-imidazol-2-thione (Scheme 2, IV), with $n \mathrm{BuLi}$ in the presence of a phosphine affords phosphino-bridged di-thiones $(\mathbf{V}){ }^{22}$ Interestingly, in contrast to the established protocol to $\mathrm{NHCs}^{24}$ reaction of $(\mathbf{V})$ with potassium metal does not yield the expected phosphino-bridged Di-NHC (VI) but an imidazolium phosphanide zwitterion (VII). ${ }^{22}$ Silyl-functionalized monoNHCs (Scheme 1, II and III) can be prepared starting from an NHC (Scheme 1); ${ }^{17-19}$ however, to the best of our knowledge no Di-NHC has been synthesized so far. Therefore, we became interested in developing a protocol for synthesis of Di-NHCs via direct C4-functionalization of an NHC.

Herein, we report a straightforward route to C4-bridged Di-NHCs, $\mathrm{R}_{2} \mathrm{Si}\left(\mathrm{IPr}^{\mathrm{H}}\right)_{2}(\mathrm{R}=\mathrm{Ph}, 2 ; \mathrm{Me}, 3)$ and a copper complex $\mathrm{Ph}_{2} \mathrm{Si}\left\{\left(\operatorname{IPr}^{\mathrm{H}}\right) \mathrm{CuCl}_{2}\right.$ (5) (Schemes 3 and 4). A Similar protocol also allows access to silyl-functionalized mono-NHC, $\mathrm{Ph}_{2}(\mathrm{Cl}) \mathrm{Si}$ $\left(\operatorname{IPr}^{\mathrm{H}}\right)(4)$ with a pendant chloro-substituent.

\section{Results and discussion}

Di-NHCs 2 and 3 have been prepared (Scheme 3) in almost quantitative yield on treatment of $\left\{\operatorname{Li}\left(\operatorname{IPr}^{\mathrm{H}}\right)\right\}_{n}$ (1) with an appropriate dihalosilane. Silyl-functionalized mono-NHC, $\mathrm{Ph}_{2}(\mathrm{Cl}) \mathrm{Si}$ (IPr) (4) is also accessible on treatment of $\mathbf{1}$ with one equiv. of

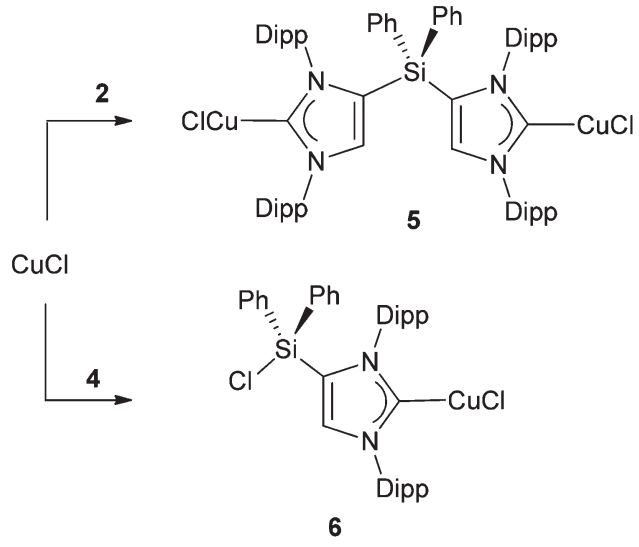

Scheme 4 Synthesis of NHC copper complexes (5) and (6).

$\mathrm{Ph}_{2} \mathrm{SiCl}_{2}$ (Scheme 3) in $82 \%$ yield. Compounds $\mathbf{2 - 4}$ are colorless crystalline solids, which are soluble in common organic solvents (benzene, toluene, and THF). They are stable under an inert atmosphere of nitrogen or argon gas. The EI-mass spectrum of 2 exhibits the molecular ion peak at $956.6 \mathrm{amu}$. A comparison of the NMR spectral data of 2-4 with those of the unfunctionalized NHC, IPr (IPr $=\left\{\left(\mathrm{N}-2,6-i \mathrm{Pr}_{2} \mathrm{C}_{6} \mathrm{H}_{3}\right) \mathrm{CH}\right\}_{2} \mathrm{C}$ : $)$ exhibits significant differences. For instance, imidazol backbone protons ( $\mathrm{NCH}$ ) of 2 appear as a singlet at $\delta 7.65 \mathrm{ppm}$ (in $\mathrm{C}_{6} \mathrm{D}_{6}$ ), which are shifted by $\delta 1.03 \mathrm{ppm}$ down field when compared with $\operatorname{IPr}\left(\delta 6.62 \mathrm{ppm}\right.$ in $\left.\mathrm{C}_{6} \mathrm{D}_{6}\right){ }^{25}$ This significant chemical shift may be attributed due to the presence of electron withdrawing phenyl groups on the silicon atom. As expected, $\mathrm{NCH}$ protons of 3 exhibit a singlet at $\delta 7.16 \mathrm{ppm}$ (in THF- $d_{8}$ ), which are shifted slightly up field than those of IPr $\left(\delta 7.18 \mathrm{ppm}\right.$, in THF- $\left.d_{8}\right)$. The ${ }^{1} \mathrm{H}$ NMR spectrum of 2 shows a remarkably high field signal for two isopropyl groups $\left(\delta 0.65 \mathrm{ppm}, 12 \mathrm{H}, \mathrm{HCMe}_{2}\right.$ ), which may be inferred as the shielding contributions from the $\pi$-current density of adjacent phenyl substituents of the $\mathrm{SiPh}_{2}$ moiety. This is consistent with the solid state structure of 2 and thus the structure is maintained in the solution state. This feature is not available in 3, therefore $\mathrm{HCMe}_{2}$ protons appear in the expected region. The ${ }^{13} \mathrm{C}$ NMR spectrum of 2 and 3 each exhibits resonances consistent with their ${ }^{1} \mathrm{H}$ NMR spectral data. Each of the NHCs 2 and 3 shows a signal at $\delta 225.19$ and $225.12 \mathrm{ppm}$ for the carbene carbon atom. Each of the compounds $2(\delta-31.17)$ and $3(\delta-22.14 \mathrm{ppm})$ exhibits a signal in the ${ }^{29} \mathrm{Si}\left\{{ }^{1} \mathrm{H}\right\}$ NMR spectrum, which is consistent with those observed for four-coordinate organosilicon compounds. ${ }^{17-19,26}$ The ${ }^{1} \mathrm{H}$ and ${ }^{13} \mathrm{C}$ NMR signals of $\mathbf{4}$ are fully in agreement with its solid state structure. Compound 4 exhibits a signal at $\delta-9.19 \mathrm{ppm}$ in the ${ }^{29} \mathrm{Si}\left\{{ }^{1} \mathrm{H}\right\}$ NMR spectrum. ${ }^{26 a}$

The molecular structure of 2 was established by a single crystal X-ray diffraction study, which clearly reveals the formation of a Di-NHC (Fig. 1). Compound 2 crystallizes in the monoclinic space group $P 2_{1} / c$. The silicon atom in 2 is fourfold coordinated and bridges two flanking NHC moieties. Each of the imidazol-rings features a delocalized $\pi$-electron system with short single and long double bonds. The N1-C2-N3 bond 


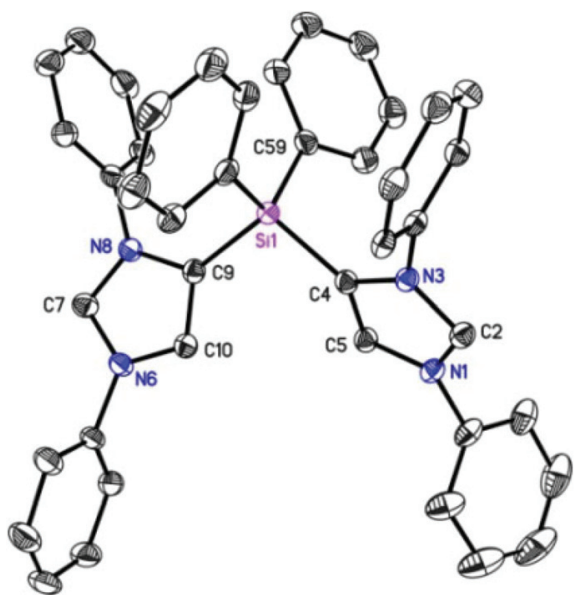

Fig. 1 Molecular structure of Di-NHC 2. Isopropyl groups and hydrogen atoms have been omitted for clarity; anisotropic displacement parameters are depicted at the $50 \%$ probability level. Selected bond lengths [Å] and angles [ $\left.{ }^{\circ}\right]$ : N1-C2 1.367(2), N1-C5 1.385(2), N3-C2 1.3669(19), C4-C5 1.358(2), Si1-C4 1.8791(16), Si1-C59 1.8760(17); N1-C2-N3 101.65(13), N3-C4-C5 103.50(13), C4-Si1-C59 107.08(7), C4-Si1-C9 104.24(7).

angle of 101.65(13) further supports the carbene character of the C2 carbon. $^{8}$ The Si1-C4 (imidazol) and Si1-C59 (Ph) (av. $1.87 \AA$ ) bond lengths are equal to the sum of the covalent radii of $\mathrm{Si}$ and $\mathrm{C}^{27}$

Compound 4 crystallizes in the triclinic space group $P \overline{1}$. The molecular structure of $\mathbf{4}$ shows functionalization of the $\mathrm{C} 4$ carbon atom with $\mathrm{Si}(\mathrm{Cl}) \mathrm{Ph}_{2}$ (Fig. 2). The Si1-Cl1 bond length of 2.0701(8) $\AA$ is consistent with those measured for the com-

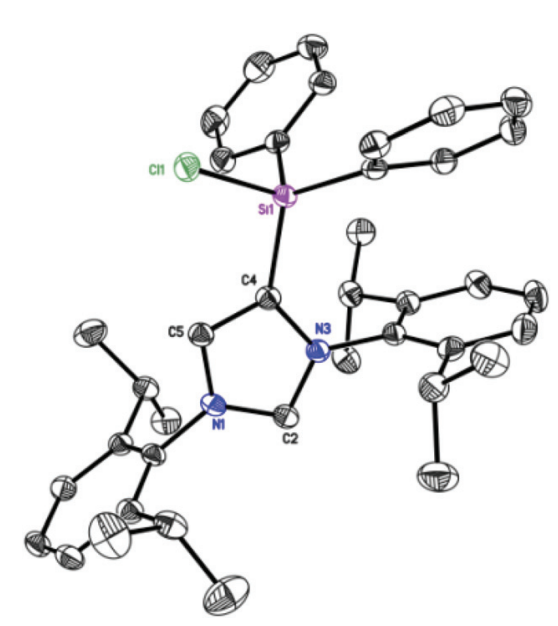

Fig. 2 Molecular structure of mono-NHC 4. Hydrogen atoms have been omitted for clarity; anisotropic displacement parameters are depicted at the $50 \%$ probability level. Selected bond lengths $[\AA]]$ and angles [']: N1-C2 1.3732(19), N1-C5 1.3799(19), N3-C2 1.3678(19), C4-C5 1.355(2), Si1-Cl1 2.0701(8), Si1-C4 1.8575(15), Si1-C36 1.8562(16); N1-C2-N3 100.79(12), N3-C4-C5 103.82(12), C4-Si1-C36 117.75(7), C4-Si1-Cl1 101.93(6). pounds with four coordinate silicon atoms. ${ }^{26 a, 27}$ The four-fold coordinated silicon atom adopts a distorted tetrahedral geometry.

NHCs 2 and 4 each reacts with $\mathrm{CuCl}$ and affords complexes $\mathrm{Ph}_{2} \mathrm{Si}\left\{\left(\mathrm{IPr}^{\mathrm{H}}\right) \mathrm{CuCl}_{2}\right.$ (5) and $\mathrm{Ph}_{2}(\mathrm{Cl}) \mathrm{Si}\left\{\left(\operatorname{IPr}^{\mathrm{H}}\right) \mathrm{CuCl}\right\}$ (6), respectively (Scheme 4). Complexes 5 and $\mathbf{6}$ are colorless crystalline solids, soluble in THF and $\mathrm{CH}_{2} \mathrm{Cl}_{2}$, and stable under an inert gas atmosphere. Formation of $\mathbf{5}$ and $\mathbf{6}$ is supported by the appearance of the corresponding molecular ion peak in the EI-mass spectrum. The ${ }^{1} \mathrm{H}$ NMR spectrum of each of compounds 5 and 6 shows signals for NHC moieties. Appearance of a new signal in the ${ }^{13} \mathrm{C}$ NMR spectrum of 5 at $\delta 186.3 \mathrm{ppm}$ is assigned for the carbene carbon atom $(\mathrm{C}-\mathrm{Cu})$. Complexes 5 and 6 show a ${ }^{29} \mathrm{Si}\left\{{ }^{1} \mathrm{H}\right\}$ NMR resonance at $\delta-30.10$ and -10.95 ppm. ${ }^{17-19,26}$

Complex 5 crystallizes in the orthorhombic space group Pna $2_{1}{ }^{25}$ The molecular structure of 5 reveals that each of the carbene centers coordinates to a $\mathrm{CuCl}$ moiety (Fig. 3). The $\mathrm{Cu}-\mathrm{C}_{\text {(carbene) }}$ bond length of $1.886 \AA$ (av.) and slightly distorted linear geometry with $\mathrm{C}-\mathrm{Cu}-\mathrm{Cl}$ angles of $174.14^{\circ}$ (av.) are consistent with those of reported NHC-copper complexes. ${ }^{17 b, 28}$ The $\mathrm{Cu}-\mathrm{Cl}$ bond length of $2.11 \AA$ (av.) may be assigned for the terminal CuCl. ${ }^{17 b, 28}$ The four-fold coordinated silicon atom adopts distorted tetrahedral geometry with a significant decrease in the C4-Si1-C9 bond angle of 98.63(14). The molecular structure of 6 is shown in Fig. 4. Complex 6 crystallizes in the monoclinic space group $P 2_{1} / c$. The copper atom in 6 features a distorted linear geometry with $\mathrm{C} 2-\mathrm{Cu} 1-\mathrm{Cl} 1$ bond angle of $174.02(5)^{\circ}$. As expected for both complexes 5 and $\mathbf{6}$, the $\mathrm{N}-\mathrm{C}-\mathrm{N}$ bond angle increases by $2.9^{\circ}$ (av.) on coordination of the carbene carbon to $\mathrm{CuCl}$.

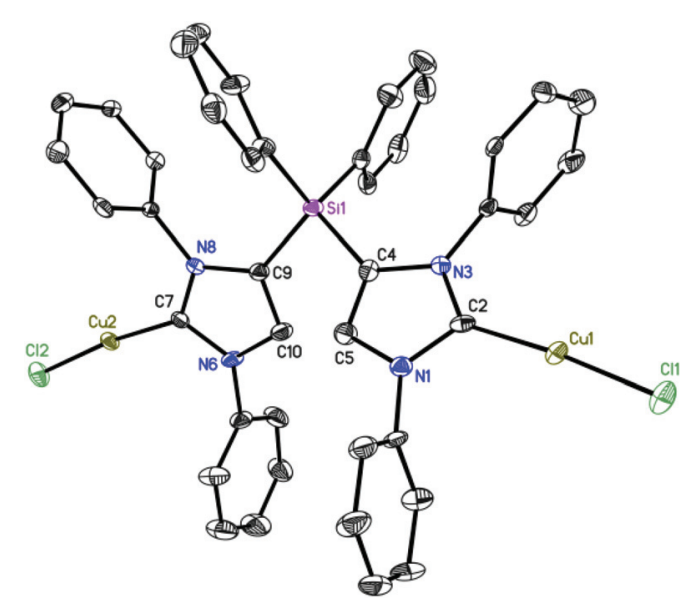

Fig. 3 Molecular structure of dicopper complex 5. Isopropyl groups and hydrogen atoms have been omitted for clarity; anisotropic displacement parameters are depicted at the $50 \%$ probability level. Selected bond lengths $[\AA \AA]$ and angles [०]: Cu1-C2 1.898(5), Cu1-Cl1 2.1116(15), Cu2-C7 1.875(5), Cu2-Cl2 2.1152(14), N1-C2 1.362(6), N1-C5 1.367(7), N3-C2 1.350(6), C4-C5 1.350(7), Si1-C4 1.888(5), Si1-C59 1.858(5); C2-Cu1-Cl1 174.84(15), N1-C2-N3 104.5(4), N3-C4-C5 104.6(4), C4Si1-C59 108.9(2), C4-Si1-C9 98.63(14). 


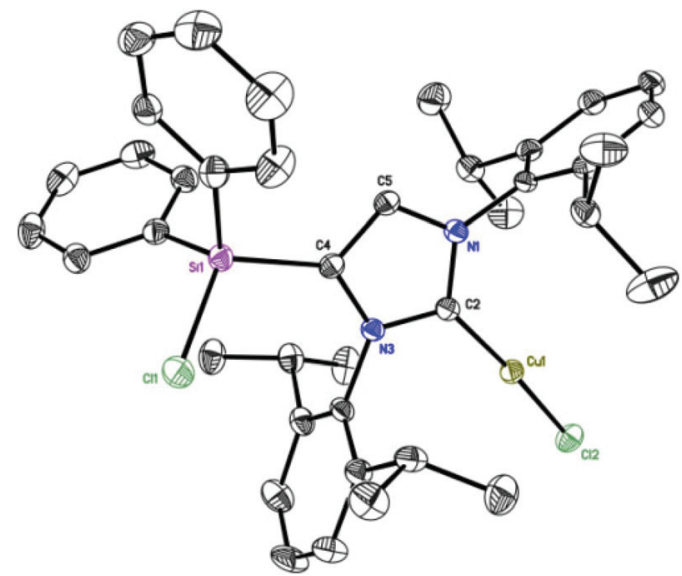

Fig. 4 Molecular structure of complex 6. Hydrogen atoms have been omitted for clarity; anisotropic displacement parameters are depicted at the $50 \%$ probability level. Selected bond lengths [Å] and angles [ $\left.{ }^{\circ}\right]$ : Cu1C2 1.8779(16), Cu1-Cl2 2.1076(5), N1-C2 1.3610(19), N1-C5 1.376(2), N3-C2 1.357(2), C4-C5 1.360(2), Si1-Cl1 2.0527(6), Si1-C4 1.8615(16), Si1-C36 1.8623(17); C2-Cu1-Cl2 174.02(5), N1-C2-N3 103.73(12), N3C4-C5 104.31(13), C4-Si1-C36 106.12(7), C4-Si1-Cl1 110.09(5).

\section{Experimental}

\section{General}

All synthesis and manipulations were carried out under an inert atmosphere of dry argon gas using Schlenk line techniques or Glove-box. $\mathrm{C}_{6} \mathrm{D}_{6}$ and THF- $d_{8}$ were dried over Kbenzophenone ketyl and distilled under dry argon atmosphere prior to use. $\mathrm{CD}_{2} \mathrm{Cl}_{2}$ was dried over $\mathrm{CaH}_{2}$ and distilled under dry argon prior to use. All other solvents were dried and purified by a MBRAUN solvent purification system (MB SPS 800). ${ }^{1} \mathrm{H},{ }^{13} \mathrm{C}$, and ${ }^{29} \mathrm{Si}$ NMR spectra were recorded using a Bruker Avance III 300 spectrometer. EI-mass spectra were recorded with MAT $95(70 \mathrm{eV})$. Elemental analyses were performed at the Institute for Inorganic Chemistry, Universität Göttingen. $\mathrm{Ph}_{2} \mathrm{SiCl}_{2}$ and $\mathrm{Me}_{2} \mathrm{SiCl}_{2}$ were distilled prior to use. Anhydrous $\mathrm{CuCl}$ (Aldrich) was used as received. Compound $\left\{\operatorname{Li}\left(\operatorname{IPr}^{\mathrm{H}}\right)\right\}_{n}(\mathbf{1})$ was prepared according to the reported method. ${ }^{19 a}$

Synthesis of $\mathbf{P h}_{2} \mathbf{S i}(\mathbf{I P r H})_{2}$ (2). To a $100 \mathrm{~mL}$ toluene suspension of $\operatorname{Li}\left(\operatorname{IPr}^{\mathrm{H}}\right)(\mathbf{1})(6.38 \mathrm{~g}, 16.17 \mathrm{mmol})$ was added a $40 \mathrm{~mL}$ toluene solution of $\mathrm{Ph}_{2} \mathrm{SiCl}_{2}(2.04 \mathrm{~g}, 8.08 \mathrm{mmol})$ at $-78{ }^{\circ} \mathrm{C}$ with constant stirring. The resulting reaction mixture was brought to room temperature and stirred overnight. During this time the yellowish reaction mixture turned to brown suspension. The reaction mixture was further stirred at $90{ }^{\circ} \mathrm{C}$ for 4 h. Filtration through Celite afforded a wine red solution. Removal of the volatiles under vacuum gave a brownish solid. The resulting solid was re-dissolved in a $30 \mathrm{~mL} n$-hexanetoluene $(2: 1)$ mixture and stored at $4{ }^{\circ} \mathrm{C}$ for two days to yield colorless crystals of $\mathrm{Ph}_{2} \mathrm{Si}\left(\operatorname{IPr}^{\mathrm{H}}\right)_{2}$ (2). Yield: $6.48 \mathrm{~g}, 84 \%$. Anal calcd for $\mathrm{C}_{66} \mathrm{H}_{80} \mathrm{~N}_{4} \mathrm{Si}$ (957): $\mathrm{C} 82.79, \mathrm{H}$ 8.42, N 5.85; found $\mathrm{C} 82.72, \mathrm{H}$ 8.44, N 5.66. ${ }^{1} \mathrm{H}$ NMR (300 MHz, $\left.\mathrm{C}_{6} \mathrm{D}_{6}, 25{ }^{\circ} \mathrm{C}\right): \delta$ 0.65 (d, 12H, $J=6.82 \mathrm{~Hz}, \mathrm{HCMe}_{2}$ ); 1.19 (d, 12H, $J=6.97 \mathrm{~Hz}$, $\mathrm{HCMe}_{2}$ ); 1.22, 125 (dd, 24H, $J=6.74 \mathrm{~Hz}, 6.79 \mathrm{~Hz}, \mathrm{HCMe}_{2}$ ); 2.64 (sept, $4 \mathrm{H}, J=6.79 \mathrm{~Hz}, H \mathrm{CMe}_{2}$ ); 3.14 (sept, $4 \mathrm{H}, J=6.90 \mathrm{~Hz}$, $H \mathrm{CMe}_{2}$ ); 6.76 (d, $\left.4 \mathrm{H}, J=7.76 \mathrm{~Hz}, m-\mathrm{C}_{6} H_{3}\right) ; 6.91$ (d, $J=7.45 \mathrm{~Hz}$, $\left.m-\mathrm{C}_{6} H_{3}\right) ; 7.00\left(\mathrm{~m}, 6 \mathrm{H}, o-, p-\mathrm{C}_{6} H_{5}\right) ; 7.10-7.19\left(\mathrm{~m}, 4 \mathrm{H}, m-\mathrm{C}_{6} H_{5}\right)$; $7.29\left(\mathrm{t}, 4 \mathrm{H}, p-\mathrm{C}_{6} H_{3}\right) ; 7.65(\mathrm{~s}, 2 \mathrm{H}, \mathrm{NCH}) \mathrm{ppm} .{ }^{13} \mathrm{C}\left\{{ }^{1} \mathrm{H}\right\} \mathrm{NMR}$ (75 MHz, $\left.\mathrm{C}_{6} \mathrm{D}_{6}, 25{ }^{\circ} \mathrm{C}\right): \delta 21.02,24.10,24.23,26.18\left(\mathrm{HCMe}_{2}\right)$; 28.62, $29.01\left(\mathrm{HCMe}_{2}\right)$; 122.84, 123.70, 130.10, 134.54, 136.54, 138.19, $139.12\left(\mathrm{CHCH}, \mathrm{C}_{6} \mathrm{H}_{3}, \mathrm{C}_{6} \mathrm{H}_{5}\right), 146.02$ (ipso- $\mathrm{C}_{6} \mathrm{H}_{3}$ ), 225.19 $(\mathrm{NCN}) \quad$ ppm. ${ }^{29} \mathrm{Si}\left\{{ }^{1} \mathrm{H}\right\} \quad \mathrm{NMR} \quad\left(59 \mathrm{MHz}, \mathrm{C}_{6} \mathrm{D}_{6}, \quad 25{ }^{\circ} \mathrm{C}\right)$ : $\delta-31.17$ ppm. EI-MS: $m / z$ (\%): 956.6 (85) $\left[\mathrm{M}^{+}\right], 387.4$ (100) $\left[\operatorname{IPr}^{\mathrm{H}+}\right]$.

$\mathbf{P h}_{2} \mathbf{S i}\left(\operatorname{IPr}^{\mathbf{H}}\right)_{2}$ (2). ${ }^{1} \mathrm{H}$ NMR (300 MHz, THF- $\left.d_{8}, 25{ }^{\circ} \mathrm{C}\right): \delta 0.52$ $\left(\mathrm{d}, 12 \mathrm{H}, J=6.83 \mathrm{~Hz}, \mathrm{HCMe}_{2}\right) ; 0.96(\mathrm{~d}, 12 \mathrm{H}, J=6.77 \mathrm{~Hz}$, $\mathrm{HCMe}_{2}$ ); 1.17, 1.19 (dd, 24H, $J=6.95,6.87 \mathrm{~Hz}, \mathrm{HCMe}_{2}$ ); 2.41 (sept, $4 \mathrm{H}, J=6.77 \mathrm{~Hz}, H \mathrm{CMe}_{2}$ ); 2.95 (sept, $4 \mathrm{H}, J=6.89 \mathrm{~Hz}$, $\mathrm{HCMe}_{2}$ ); 6.73 (d, $\left.4 \mathrm{H}, J=7.76 \mathrm{~Hz}, m-\mathrm{C}_{6} H_{3}\right) ; 6.94(\mathrm{~d}, J=7.35 \mathrm{~Hz}$, $\left.m-\mathrm{C}_{6} H_{3}\right) ; 7.01$ (m, 6H, o-, $\left.p-\mathrm{C}_{6} H_{5}\right) ; 7.12-7.21$ (m, $4 \mathrm{H}, m-\mathrm{C}_{6} H_{5}$ ); 7.46 (s, 2H, NCH) ppm. ${ }^{13} \mathrm{C}\left\{{ }^{1} \mathrm{H}\right\}$ NMR (75 MHz, THF- $\left.d_{8}, 25{ }^{\circ} \mathrm{C}\right)$ : $\delta$ 21.88, 24.35, 25.10, $25.22\left(\mathrm{HCMe}_{2}\right) ; 29.82,30.11\left(\mathrm{HCMe}_{2}\right)$; 123.89, 124.50, 124.76 128.99, 129.95, 130.71, 135.75, 137.86, 139.47, $140.34\left(\mathrm{C}_{6} \mathrm{H}_{3}, \mathrm{C}_{6} \mathrm{H}_{5}\right), 147.11,147.35$ (ipso- $\left.\mathrm{C}_{6} \mathrm{H}_{3}\right), 226.31$ (NCN) ppm.

Synthesis of $\mathrm{Me}_{2} \mathrm{Si}\left(\mathrm{IPr}^{\mathrm{H}}\right)_{2}$ (3). Compound 3 was prepared in $79 \%$ yield adopting a similar method as described for the compound 2, using (1) (2.23 g, $5.65 \mathrm{mmol})$ and $\mathrm{Me}_{2} \mathrm{SiCl}_{2}(0.35 \mathrm{~mL}$, $2.90 \mathrm{mmol}$ ). Anal. calcd for $\mathrm{C}_{56} \mathrm{H}_{76} \mathrm{~N}_{4} \mathrm{Si}$ (833): C 80.71, H 9.19, $\mathrm{N}$ 6.72; found $\mathrm{C} 79.98, \mathrm{H} 9.09, \mathrm{~N} 6.39 .{ }^{1} \mathrm{H}$ NMR $(300 \mathrm{MHz}$, THF- $\left.d_{8}, 25{ }^{\circ} \mathrm{C}\right): \delta-0.30\left(\mathrm{~s}, 6 \mathrm{H}, \mathrm{SiMe} e_{2}\right), 1.04(\mathrm{~d}, 12 \mathrm{H}, J=6.94$ $\mathrm{Hz}, \mathrm{HCMe}_{2}$ ); 1.11 (d, 12H, $J=6.67 \mathrm{~Hz}, \mathrm{HCMe}_{2}$ ); 1.16, 1.18 (dd, 24H, $\mathrm{HCMe}_{2}$ ); 2.62 (sept, $4 \mathrm{H}, J=6.83 \mathrm{~Hz}, H \mathrm{CMe}_{2}$ ); 2.82 (sept, $\left.4 \mathrm{H}, J=6.91 \mathrm{~Hz}, \mathrm{HCMe}_{2}\right) ; 7.16(\mathrm{~s}, 2 \mathrm{H}, \mathrm{NCH}), 7.22(\mathrm{~m}, 8 \mathrm{H}$, $\left.m-\mathrm{C}_{6} H_{3}\right) ; 7.35\left(\mathrm{~m}, 4 \mathrm{H}, p-\mathrm{C}_{6} H_{3}\right) . \mathrm{ppm} .{ }^{13} \mathrm{C}\left\{{ }^{1} \mathrm{H}\right\}$ NMR $(75 \mathrm{MHz}$, THF- $\left.d_{8}, \quad 25{ }^{\circ} \mathrm{C}\right): \quad \delta \quad 0.49 \quad\left(\mathrm{SiMe}_{2}\right), \quad 22.76, \quad 24.37, \quad 24.66$, $25.49\left(\mathrm{HCMe}_{2}\right) ; 29.65,29.82,30.10\left(\mathrm{HCMe}_{2}\right) ; 123.08,124.33$, 124.49, 124.61, 129.78, 129.94, 130.20, 131.71, 134.06, 139.58, 140.23, $140.88\left(\mathrm{C}_{6} \mathrm{H}_{3}\right), 147.05,147.32,147.62$ (ipso- $\mathrm{C}_{6} \mathrm{H}_{3}$ ), $225.12(\mathrm{NCN})$ ppm. ${ }^{29} \mathrm{Si}\left\{{ }^{1} \mathrm{H}\right\}$ NMR (59 MHz, THF- $\left.d_{8}, 25{ }^{\circ} \mathrm{C}\right)$ : $\delta-22.14 \mathrm{ppm}$.

Synthesis of $\mathbf{P h}_{2}(\mathrm{Cl}) \mathrm{Si}\left(\operatorname{IPr}^{\mathrm{H}}\right)$ (4). To a toluene suspension of (1) $(1.87 \mathrm{~g}, 4.74 \mathrm{mmol})$ was added a $50 \mathrm{~mL}$ toluene solution of $\mathrm{Ph}_{2} \mathrm{SiCl}_{2}(1 \mathrm{~mL}, 4.74 \mathrm{mmol})$ at $-78{ }^{\circ} \mathrm{C}$. The reaction mixture was brought to room-temperature and stirred overnight. Filtration through Celite afforded yellowish solution. Removal of all the volatiles under vacuum yielded a yellow solid. Colorless crystals of 4 (2.36 g, 82\%) were recovered after one week on storage of a saturated toluene solution at $-25{ }^{\circ} \mathrm{C} .{ }^{1} \mathrm{H}$ NMR (300 MHz, THF- $\left.d_{8}, 25{ }^{\circ} \mathrm{C}\right): \delta 0.74\left(\mathrm{~d}, 6 \mathrm{H}, J=6.86 \mathrm{~Hz}, \mathrm{HCMe}_{2}\right.$ ), $1.06\left(\mathrm{~d}, 6 \mathrm{H} J=6.79 \mathrm{~Hz}, \mathrm{HCMe}_{2}\right), 1.18(\mathrm{~d}, 6 \mathrm{H}, J=6.85 \mathrm{~Hz}$, $\mathrm{HCMe}_{2}$ ), 1.22 (d, 6H, $J=6.94 \mathrm{~Hz}, \mathrm{HCMe}_{2}$ ), 2.52 (sept, 2H, $J=$ $6.85 \mathrm{~Hz}, H \mathrm{CMe}_{2}$ ), 2.87 (sept, $2 \mathrm{H}, J=6.92 \mathrm{~Hz}, H \mathrm{CMe}_{2}$ ), 7.06 $\left(\mathrm{d}, 2 \mathrm{H}, J=7.80 \mathrm{~Hz}, m-\mathrm{C}_{6} \mathrm{H}_{3}\right), 7.25-7.44\left(\mathrm{~m}, 15 \mathrm{H}, \mathrm{C}_{6} \mathrm{H}_{5}, \mathrm{C}_{6} \mathrm{H}_{3}\right.$, $\mathrm{NCH})$ ppm. ${ }^{13} \mathrm{C}\left\{{ }^{1} \mathrm{H}\right\} \mathrm{NMR}\left(75 \mathrm{MHz}, \mathrm{THF}-d_{8}, 25{ }^{\circ} \mathrm{C}\right): \delta 21.25$, 24.02, 24.28, 26.05 $\left(\mathrm{HCMe}_{2}\right), 28.99,29.52\left(\mathrm{HCMe}_{2}\right), 123.51$, 123.89, 125.83, 126.58, 128.68, 129.23, 129.35, 129.46, 131.43, 132.63, 135.57, 136.34, 138.57, $139.51\left(\mathrm{C}_{6} \mathrm{H}_{3}, \mathrm{C}_{6} \mathrm{H}_{5}\right), 146.35$, 146.83 (ipso- $\mathrm{C}_{6} \mathrm{H}_{3}$ ), $225.88(\mathrm{NCN}) \mathrm{ppm} .{ }^{29} \mathrm{Si}\left\{{ }^{1} \mathrm{H}\right\}-\mathrm{NMR}(59 \mathrm{MHz}$, THF- $\left.d_{8}, 25^{\circ} \mathrm{C}\right): \delta-9.19 \mathrm{ppm}$. 
Synthesis of $\mathbf{P h}_{2} \mathrm{Si}\left\{\left(\operatorname{IPr}^{\mathbf{H}}\right) \mathbf{C u C l}\right\}_{2}$ (5). To a Schlenk flask containing 2 (0.52 g, $0.54 \mathrm{mmol})$ and anhydrous $\mathrm{CuCl}(0.11 \mathrm{~g}$, $1.11 \mathrm{mmol}$ ) was added $20 \mathrm{~mL}$ of THF. Resulting suspension was stirred overnight at room temperature. Removal of the volatiles under vacuum afforded off-white solid, which was washed with $(2 \times 20 \mathrm{~mL}) n$-hexane. The residue was dissolved in $5 \mathrm{~mL}$ of $\mathrm{CH}_{2} \mathrm{Cl}_{2}$ and combined with $10 \mathrm{~mL}$ of $n$-hexane. The solution was stored at $-35{ }^{\circ} \mathrm{C}$ to obtain colorless crystals of $\mathbf{5}$ in $81 \%$ (0.51 g) yield. Anal. calcd for $\mathrm{C}_{66} \mathrm{H}_{80} \mathrm{~N}_{4} \mathrm{Cl}_{2} \mathrm{Cu}_{2} \mathrm{Si}$ (1155): $\mathrm{C}$ 68.61, $\mathrm{H}$ 6.98, N 4.85; found $\mathrm{C} 67.55, \mathrm{H} 6.85, \mathrm{~N} 4.91$. ${ }^{1} \mathrm{H}$ NMR $\left(300 \mathrm{MHz}, \mathrm{CD}_{2} \mathrm{Cl}_{2}, 25{ }^{\circ} \mathrm{C}\right): \delta 0.50(\mathrm{~d}, 12 \mathrm{H}, J=6.63 \mathrm{~Hz}$, $\left.\mathrm{HCMe}_{2}\right) ; 1.14\left(\mathrm{~d}, 12 \mathrm{H}, J=6.79 \mathrm{~Hz}, \mathrm{HCMe}_{2}\right) ; 1.31(\mathrm{~m}, 24 \mathrm{H}$, $\mathrm{HCMe}_{2}$ ); 2.18 (sept, $4 \mathrm{H}, J=6.77 \mathrm{~Hz}, \mathrm{HCMe}_{2}$ ); 2.64 (sept, 4H, $J=$ $\left.6.88 \mathrm{~Hz}, \mathrm{HCMe}_{2}\right) ; 6.85\left(\mathrm{~m}, 8 \mathrm{H}, m-\mathrm{C}_{6} \mathrm{H}_{3}\right) ; 7.08(\mathrm{t}, 4 \mathrm{H}, J=$ $\left.7.70 \mathrm{~Hz}, p-\mathrm{C}_{6} \mathrm{H}_{3}\right) ; 7.19\left(\mathrm{t}, 2 \mathrm{H}, J=7.79 \mathrm{~Hz}, p-\mathrm{C}_{6} \mathrm{H}_{5}\right) ; 7.31(\mathrm{t}, 2 \mathrm{H}$, $\left.J=6.99 \mathrm{~Hz}, m-\mathrm{C}_{6} \mathrm{H}_{5}\right) ; 7.41\left(\mathrm{~d}, 4 \mathrm{H}, J=7.76 \mathrm{~Hz}, o-\mathrm{C}_{6} \mathrm{H}_{5}\right) ; 7.50$ (s, 2H, NCH); $7.61\left(\mathrm{t}, 2 \mathrm{H}, J=7.77 \mathrm{~Hz}, m-\mathrm{C}_{6} \mathrm{H}_{5}\right) \mathrm{ppm} .{ }^{13} \mathrm{C}\left\{{ }^{1} \mathrm{H}\right\} \mathrm{NMR}$ (75 MHz, $\mathrm{CD}_{2} \mathrm{Cl}_{2}, 25^{\circ} \mathrm{C}$ ): $\delta$ 21.42, 24.44, 24.90, $27.21\left(\mathrm{HCMe}_{2}\right)$; 29.18, $29.39\left(\mathrm{HCMe}_{2}\right)$; 124.27, 124.90, 126.49, 128.72, 129.58, 131.17, 131.26, 131.33, 134.27, 134.48, 134.88, 136.48, 145.69, $146.02\left(\mathrm{C}_{6} \mathrm{H}_{5}, \mathrm{C}_{6} \mathrm{H}_{3}\right), 186.27(\mathrm{NCN}) \quad$ ppm. ${ }^{29} \mathrm{Si}\left\{{ }^{1} \mathrm{H}\right\} \quad \mathrm{NMR}$ (59 MHz, $\mathrm{CD}_{2} \mathrm{Cl}_{2}, 25{ }^{\circ} \mathrm{C}$ ): $\delta-30.10 \mathrm{ppm}$. EI-MS: $\mathrm{m} / \mathrm{z}: 1154.3$ $\left(\mathrm{M}^{+}\right), 1054.5\left(\mathrm{M}^{+}-\mathrm{CuCl}\right), 956.6\left(\mathrm{M}^{+}-2 \mathrm{CuCl}\right)$.

Synthesis of $\mathbf{P h}_{\mathbf{2}}(\mathbf{C l}) \operatorname{Si}\left\{\left(\operatorname{IPr}^{\mathbf{H}}\right) \mathbf{C u C l}\right\}$ (6). To a $100 \mathrm{~mL}$ Schlenk flask containing 4 (360 $\mathrm{mg}, 0.6 \mathrm{mmol})$ and anhydrous $\mathrm{CuCl}$ (60 mg, $0.6 \mathrm{mmol}$ ) was added $50 \mathrm{~mL}$ toluene and stirred overnight. Filtration through Celite afforded yellowish solution, which was concentrated $(20 \mathrm{~mL})$ under vacuum and stored at $0{ }^{\circ} \mathrm{C}$ to yield colorless crystals of 7 (335 mg, 80\%). Anal. calcd for $\mathrm{C}_{40} \mathrm{H}_{46} \mathrm{~N}_{2} \mathrm{Cl}_{2} \mathrm{Cu}$ (704.33) C 66.51, $\mathrm{H}$ 6.44, N 3.98; found C 66.95, H 6.25, N 3.88. ${ }^{1} \mathrm{H}$ NMR (300 MHz, THF- $\left.d_{8}, 25{ }^{\circ} \mathrm{C}\right)$ : $\delta 0.75\left(\mathrm{~d}, 6 \mathrm{H}, J=6.81 \mathrm{~Hz}, \mathrm{HCMe}_{2}\right), 1.26(\mathrm{~d}, 6 \mathrm{H}, J=3.99 \mathrm{~Hz}$, $\mathrm{HCMe}_{2}$ ), 1.28 (d, 6H, $J=4.07 \mathrm{~Hz}, \mathrm{HCMe}_{2}$ ), 1.32 (d, 6H, $J=6.88$ $\mathrm{Hz}, \mathrm{HCMe}_{2}$ ), 2.41 (sept, $2 \mathrm{H}, J=6.81 \mathrm{~Hz}, \mathrm{HCMe}_{2}$ ), 2.69 (sept, $\left.2 \mathrm{H}, J=6.90 \mathrm{~Hz}, H \mathrm{CMe}_{2}\right), 7.19$ (d, $2 \mathrm{H}, J=7.83 \mathrm{~Hz}, m-\mathrm{C}_{6} \mathrm{H}_{3}$ ), 7.35-7.52 (m, 15H, $\left.\mathrm{C}_{6} \mathrm{H}_{5}, \mathrm{C}_{6} \mathrm{H}_{3}\right), 7.89(\mathrm{~s}, 1 \mathrm{H}, \mathrm{NCH}) \mathrm{ppm}$. ${ }^{13} \mathrm{C}\left\{{ }^{1} \mathrm{H}\right\}$-NMR (75 MHz, THF- $d_{8}, 25{ }^{\circ} \mathrm{C}$ ): $\delta$ 22.20, 24.13, 24.34, $24.91\left(\mathrm{HCMe}_{2}\right), 25.10,27.07,29.92,30.14\left(\mathrm{HCMe}_{2}\right), 125.05$, 125.08, 125.79, 129.35, 129.45, 131.41, 131.56, 131.70, 135.96, $137.38\left(\mathrm{C}_{6} \mathrm{H}_{5}, \mathrm{C}_{6} \mathrm{H}_{3}\right), 146.64,147.02\left(\right.$ ipso- $\left.\mathrm{C}_{6} \mathrm{H}_{3}\right), 186.82(\mathrm{NCN})$ ppm. ${ }^{29} \mathrm{Si}\left\{{ }^{1} \mathrm{H}\right\}-\mathrm{NMR}\left(59 \mathrm{MHz}, \mathrm{THF}-d_{8}, 25{ }^{\circ} \mathrm{C}\right) \delta-10.95 \mathrm{ppm}$. MS (EI): $m / z: 703.9(\mathrm{M}), 603.1$ (M - CuCl), 387.28 (IPr).

\section{X-ray crystallography}

Suitable single crystals were selected from the mother liquor in the Schlenk flask and covered with perfluorinated polyether oil on a microscope slide, which was cooled with a nitrogen gas flow using the X-Temp2 device. ${ }^{29}$ The diffraction data of compound 2 were collected at $100 \mathrm{~K}$ on a Bruker D8 three circle diffractometer equipped with a SMART APEX II CCD detector and a microfocus source ${ }^{30}$ with INCOATEC Quazar mirror optics $(\lambda=0.71073 \AA)$. The diffraction data for compounds 4,5 , and 6 were collected at $100 \mathrm{~K}$ on a Bruker TXS-Mo rotating anode with mirror optics and a Smart Apex II Ultra detector. The data were integrated with SAINT $^{31}$ and a multiscan absorption correction with SADABS $^{32}$ was applied.
The structures were solved by direct methods (SHELXS-97) ${ }^{33}$ and refined against all data by full-matrix leastsquares methods on $F^{2}$ (SHELXL2013) $)^{34,35}$ within the SHELXLE GUI. ${ }^{36}$ The hydrogen atoms were refined isotropically on calculated positions using a riding model with their $U_{\text {iso }}$ values constrained to $1.5 U_{\text {eq }}$ of their pivot atoms for terminal $\mathrm{sp}^{3}$ carbon atoms and 1.2 times for all other carbon atoms. All non-hydrogen-atoms were refined with anisotropic displacement parameters. Disordered moieties were refined using distance restraints (SAME) and anisotropic displacement parameter restraints (SIMU and RIGU). ${ }^{35}$

Crystal data for 2. $\mathrm{C}_{72.44} \mathrm{H}_{87.36} \mathrm{~N}_{4} \mathrm{Si}, M_{\mathrm{r}}=1042.19,0.1 \times 0.1 \times$ $0.07 \mathrm{~mm}, a=13.646(2), b=20.372(2), c=22.809(3) \AA, \alpha=$ 90.00, $\beta=95.89(2), \gamma=90.00^{\circ}, V=6307.3(13) \AA^{3}, Z=4, \rho_{\text {calcd. }}=$ $1.098 \mathrm{Mg} \mathrm{m}^{-3}, \mu\left(\mathrm{Mo}^{-K_{\alpha}}\right)=0.081 \mathrm{~mm}^{-1}, 2 \theta_{\max }=52.1^{\circ}, 102837$ reflections measured, 12433 independent $\left(R_{\text {int }}=0.0485\right), R_{1}=$ $0.0449[I>2 \sigma(I)], \mathrm{w} R_{2}=0.1170$ (all data), residual density peaks: 0.343 to -0.259 e $\AA^{-3}$.

Crystal data for 4. $\mathrm{C}_{46} \mathrm{H}_{53} \mathrm{ClN}_{2} \mathrm{Si}, M_{\mathrm{r}}=697.44,0.19 \times 0.134 \times$ $0.09 \mathrm{~mm}, a=10.900(2), b=11.162(2), c=18.612(3) \AA, \alpha=78.13(2)$, $\beta=95.89(3), \gamma=65.94(2)^{\circ}, V=2010.3(7) \AA^{3}, Z=2, \rho_{\text {calcd. }}=$ $1.152 \mathrm{Mg} \mathrm{m}^{-3}, \mu\left(\mathrm{Mo}_{-} \mathrm{K}_{\alpha}\right)=0.152 \mathrm{~mm}^{-1}, 2 \theta_{\max }=55.0^{\circ}, 55303$ reflections measured, 9200 independent $\left(R_{\text {int }}=0.0418\right), R_{1}=$ $0.0410[I>2 \sigma(I)], \mathrm{w} R_{2}=0.1034$ (all data), residual density peaks: 0.354 to -0.346 e $\AA^{-3}$.

Crystal data for 5. $\mathrm{C}_{69} \mathrm{H}_{86} \mathrm{Cl}_{8} \mathrm{Cu}_{2} \mathrm{~N}_{4} \mathrm{Si}, M_{\mathrm{r}}=1410.18,0.368 \times$ $0.190 \times 0.964 \mathrm{~mm}, a=24.735(3), b=11.999(2), c=23.789(2) \AA$, $\alpha=90.00, \beta=90.00, \gamma=90.00^{\circ}, V=7060.5(16) \AA^{3}, Z=4, \rho_{\text {calcd. }}=$ $1.327 \mathrm{Mg} \mathrm{m}^{-3}, \mu\left(\mathrm{Mo}_{-} \mathrm{K}_{\alpha}\right)=0.964 \mathrm{~mm}^{-1}, 2 \theta_{\max }=52.7^{\circ}, 226192$ reflections measured, 14390 independent $\left(R_{\text {int }}=0.0340\right), R_{1}=$ $0.0352[I>2 \sigma(I)], \mathrm{w} R_{2}=0.0968$ (all data), residual density peaks: 0.824 to -0.561 e $\AA^{-3}$.

Crystal data for 6. $\mathrm{C}_{46} \mathrm{H}_{53} \mathrm{Cl}_{2} \mathrm{CuN}_{2} \mathrm{Si}, M_{\mathrm{r}}=796.43,0.235 \times$ $0.196 \times 0.150 \mathrm{~mm}, a=11.380(2), b=15.471(2), c=24.575(3) \AA$, $\alpha=90.00, \beta=98.03(2), \gamma=90.00^{\circ}, V=4301.9(11) \AA^{3}, Z=4$, $\rho_{\text {calcd. }}=1.230 \mathrm{Mg} \mathrm{m}^{-3}, \mu\left(\mathrm{Mo}_{\mathrm{\alpha}}\right)=0.692 \mathrm{~mm}^{-1}, 2 \theta_{\max }=52.8^{\circ}$, 97304 reflections measured, 8799 independent $\left(R_{\text {int }}=0.0519\right)$, $R_{1}=0.0288[I>2 \sigma(I)], \mathrm{w} R_{2}=0.0740$ (all data), residual density

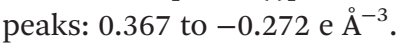

\section{Conclusions}

In conclusion, we have reported a convenient method which allows direct functionalization of an NHC to afford Di-NHCs 2 and 3 in high yield. Mono-NHC 4 with a pendant chloro-substituent is also accessible using a similar protocol. Compound 4 offers new promises to prepare novel hybrid ligands by further functionalization. Di-NHCs (2 and 3), mono-NHC (4), and copper complexes (5 and 6) are fully characterized. We believe that this method can be applied to other new functionalized Di-NHCs with different bridging moieties, such as VI. Investigation on potential application of Di-NHCs as ligands in homogeneous catalysis and as organocatalysts is currently under way to examine the scope of new Di-NHC scaffolds. 


\section{Acknowledgements}

The authors are thankful to Prof. Dr Dietmar Stalke for his generous support and encouragement.

\section{Notes and references}

1 (a) D. Bourissou, O. Guerret, F. P. Gabbaï and G. Bertrand, Chem. Rev., 2000, 100, 39-92; (b) W. A. Herrmann, Angew. Chem., 2002, 114, 1342-1363, (Angew. Chem., Int. Ed., 2002, 41, 1290-1309); (c) E. A. B. Kantchev, C. J. O'Brien and M. G. Organ, Angew. Chem., 2007, 119, 2824-2870, (Angew. Chem., Int. Ed., 2007, 46, 2768-2813); (d) F. E. Hahn and M. C. Jahnke, Angew. Chem., 2008, 120, 3166-3216, (Angew. Chem., Int. Ed., 2008, 47, 3122-3172); (e) S. Díez-González, N. Marion and S. P. Nolan, Chem. Rev., 2009, 109, 36123676; (f) R. Wolf and W. Uhl, Angew. Chem., 2009, 121, 6905-6907, (Angew. Chem., Int. Ed., 2009, 48, 6774-6776).

2 (a) N-Heterocyclic Carbenes in Synthesis, ed. S. P. Nolan, Wiley-VCH, Weinheim, Germany, 2006; (b) N-Heterocyclic Carbenes in Transition Metal Catalysis, ed. F. Glorius, Springer, Berlin, 2007; (c) N-Heterocyclic Carbenes in Transition Metal Catalysis and Organocatalysis, ed. C. S. J. Cazin, Springer, Heidelberg, 2011.

3 (a) R. S. Ghadwal, R. Azhakar and H. W. Roesky, Acc. Chem. Res., 2013, 46, 444-456; (b) R. S. Ghadwal, H. W. Roesky, S. Merkel, J. Henn and D. Stalke, Angew. Chem., 2009, 121, 5793-5796, (Angew. Chem., Int. Ed., 2009, 48, 5683-5686); (c) A. C. Filippou, O. Chernov and G. Schnakenburg, Angew. Chem., 2009, 121, 5797-5800, (Angew. Chem., Int. Ed., 2009, 48, 5687-5690); (d) H. Braunschweig, R. D. Dewhurst, K. Hammond, J. Mies, K. Radacki and A. Vargas, Science, 2012, 336, 1420-1422; (e) A. Higelin, S. Keller, C. Göhringer, C. Jones and I. Krossing, Angew. Chem., 2013, 125, 5041-5044, (Angew. Chem., Int. Ed., 2013, 52, 49414944); (f) Y. Wang, Y. Xie, P. Wei, R. B. King, H. F. Schaefer III, P. von R. Schleyer and G. H. Robinson, J. Am. Chem. Soc., 2008, 130, 14970-14971; ( $g$ ) Y. Wang, Y. Xie, P. Wei, R. B. King, H. F. Schaefer III, P. von R. Schleyer and G. H. Robinson, Science, 2008, 321, 1069-1071.

4 (a) A. Gautier and F. Cisnetti, Metallomics, 2012, 4, 23-32; (b) W. Liu and R. Gust, Chem. Soc. Rev., 2013, 42, 755-773; (c) L. Oehninger, R. R. Rubbiani and I. Ott, Dalton Trans., 2013, 42, 3269-3284.

5 L. Mercs and M. Albrecht, Chem. Soc. Rev., 2010, 39, 1903-1912.

6 (a) T. Dröge and F. Glorius, Angew. Chem., 2010, 122, 7094-7107, (Angew. Chem., Int. Ed., 2010, 49, 6940-6952); (b) D. J. Nelson and S. P. Nolan, Chem. Soc. Rev., 2013, 42, 6723-6753.

7 (a) C. D. Martin, M. Soleilhavoup and G. Bertrand, Chem. Sci., 2013, 4, 3020-3030; (b) M. Albrecht, Chem. Commun., 2008, 3601-3610.

8 (a) O. Schuster, L. Yang, H. G. Raubenheimer and M. Albrecht, Chem. Rev., 2009, 109, 3445-3478; (b) M. Melaimi, M. Soleilhavoup and G. Bertrand, Angew. Chem., 2010, 122, 8992-9032, (Angew. Chem., Int. Ed., 2010, 49, 8810-8849); (c) R. H. Crabtree, Coord. Chem. Rev., 2013, 257, 755-766.

9 (a) A. B. Powell, C. W. Bielawski and A. H. Cowley, J. Am. Chem. Soc., 2010, 132, 10184-10194; (b) J. A. Mata, F. E. Hahn and E. Peris, Chem. Sci., 2014, 5, 1723-1732.

10 R. Maity, A. Rit, C. Schulte to Brinke, J. Kösters and F. E. Hahn, Organometallics, 2013, 32, 6174-6177.

11 M. Poyatos, J. A. Mata and E. Peris, Chem. Rev., 2009, 109, 3677-3707.

12 D. M. Khramov, A. J. Boydston and C. W. Bielawski, Angew. Chem., 2006, 118, 6332-6335, (Angew. Chem., Int. Ed., 2006, 45, 6186-6189).

13 M. Nussbaum, O. Schuster and M. Albrecht, Chem. - Eur. J., 2013, 19, 17517-17527.

14 B. M. Neilsona, A. G. Tennysona and C. W. Bielawski, J. Phys. Org. Chem., 2012, 25, 531-543.

15 O. Kühl, Functionalised N-Heterocyclic Carbene Complexes, John Wiley \& Sons Ltd, 2010.

16 J. Bates, P. Kennepohl and D. P. Gates, Angew. Chem., 2009, 121, 10028-10031, (Angew. Chem., Int. Ed., 2009, 48, 98449847).

17 (a) D. Mendoza-Espinosa, B. Donnadieu and G. Bertrand, J. Am. Chem. Soc., 2010, 132, 7264-7265; (b) D. MendozaEspinosa, B. Donnadieu and G. Bertrand, Chem. - Asian J., 2011, 6, 1099-1103.

18 R. S. Ghadwal, H. W. Roesky, M. Granitzka and D. Stalke, J. Am. Chem. Soc., 2010, 132, 10018-10020.

19 (a) Y. Wang, Y. Xie, M. Y. Abraham, P. Wei, H. F. Schaefer III, P. von R. Schleyer and G. H. Robinson, J. Am. Chem. Soc., 2010, 132, 14370-14372; (b) Y. Wang, M. Y. Abraham, R. J. Gilliard Jr., P. Wei, J. C. Smith and G. H. Robinson, Organometallics, 2012, 31, 791-793.

20 (a) S. Kronig, E. Theuergarten, C. G. Daniliuc, P. G. Jones and M. Tamm, Angew. Chem., 2012, 124, 3294-3298, (Angew. Chem., Int. Ed., 2012, 51, 3240-3244); (b) Y. Wang, Y. Xie, M. Y. Abraham, R. J. Gilliard Jr., P. Wei, C. F. Campana, H. F. Schaefer III, P. von R. Schleyer and G. H. Robinson, Angew. Chem., 2012, 124, 10320-10323, (Angew. Chem., Int. Ed., 2012, 51, 10173-10176).

21 For other functionalized NHCs and derivatives: (a) P. K. Majhi, S. Sauerbrey, G. Schnakenburg, A. J. Arduengo III and R. Streubel, Inorg. Chem., 2012, 51, 10408-10416; (b) J. Ruiz and A. F. Mesa, Chem. - Eur. J., 2012, 18, 4485-4488; (c) A. Solovyev, E. Lacôte and D. P. Curran, Org. Lett., 2011, 13, 6042-6045.

22 P. K. Majhi, G. Schnakenburg, Z. Kelemen, L. Nyulaszi, D. P. Gates and R. Streubel, Angew. Chem., 2013, 125, 10264-10267, (Angew. Chem., Int. Ed., 2013, 52, 1008010083).

23 E. Aldeco-Perez, A. J. Rosenthal, B. Donnadieu, P. Parameswaran, G. Frenking and G. Bertrand, Science, 2009, 326, 556-559.

24 N. Kuhn and T. Kratz, Synthesis, 1993, 561-562.

25 See ESI $\dagger$ for details. 
26 (a) R. S. Ghadwal, S. O. Reichmann, F. Engelhardt, D. M. Andrada and G. Frenking, Chem. Commun., 2013, 49, 9440-9442; (b) R. S. Ghadwal, R. Azhakar, K. Pröpper, B. Dittrich and M. John, Chem. Commun., 2013, 49, 5987-5989.

27 (a) S. K. Liew, S. M. I. Al-Rafia, J. T. Goettel, P. A. Lummis, S. M. McDonald, L. J. Miedema, M. J. Ferguson, R. McDonald and E. Rivard, Inorg. Chem., 2012, 51, 54715480; (b) F. Popp, J. B. Natscher, J. O. Daiss, C. Burschka and R. Tacke, Organometallics, 2007, 26, 6014-6028; (c) A. C. T. Kuate, S. K. Mohapatra, C. G. Daniliuc, P. G. Jones and M. Tamm, J. Organomet. Chem., 2012, 696, 4281-4292.

28 (a) H. Kaur, F. K. Zinn, E. D. Stevens and S. P. Nolan, Organometallics, 2004, 23, 1157-1160; (b) A. Szadkowska, A. Makal, K. Wozniak, R. Kadyrov and K. Grela, Organometallics, 2009, 28, 2693-2700; (c) J. Chun, I. G. Jung, H. J. Kim, M. Park, M. S. Lah and S. U. Son, Inorg. Chem., 2009, 48, 6353-6355; (d) S. Díez-González, E. C. EscuderoAdán, J. Benet-Bucholz, E. D. Stevens, A. M. Z. Slawin and S. P. Nolan, Dalton Trans., 2010, 39, 7595-7606.
29 (a) D. Stalke, Chem. Soc. Rev., 1998, 27, 171-178; (b) T. Kottke and D. Stalke, J. Appl. Crystallogr., 1993, 26, 615-619.

30 T. Schulz, K. Meindl, D. Leusser, D. Stern, J. Graf, C. Michaelsen, M. Ruf, G. M. Sheldrick and D. Stalke, J. Appl. Crystallogr., 2009, 42, 885-891.

31 SAINT, Bruker AXS Inc., Madison, Wisconsin, USA, 2000.

32 G. M. Sheldrick, $S A D A B S$, Universität Göttingen, Germany, 2000.

33 G. M. Sheldrick, Acta Crystallogr., Sect. A: Fundam. Crystallogr., 1990, 46, 467-473.

34 G. M. Sheldrick, Acta Crystallogr., Sect. A: Fundam. Crystallogr., 2008, 64, 112-122.

35 P. Müller, R. Herbst-Irmer, A. L. Spek, T. R. Schneider and M. R. Sawaya, in Crystal Structure Refinement-A Crystallographer's Guide to SHELXL, IUCr Texts on Crystallography, ed. P. Müller, Oxford University Press, Oxford, UK, vol. 8, 2006.

36 C. B. Hübschle, G. M. Sheldrick and B. Dittrich, J. Appl. Crystallogr., 2011, 44, 1281-1284. 